Viktoriia Korneshchuk,

Doctor of Pedagogy, professor,

Head of the Department of Social Work and Personnel Management, Odessa National Polytechnic University, 1, Shevchenko Avenue, Odesa, Ukraine

\title{
PROFESSIONAL TRAINING OF FUTURE SOCIAL WORKERS: FOREIGN EXPERIENCE REVIEW
}

The article is dedicated to generalization of the experience of professional training of social workers in the USA, Canada, Great Britain, France, Sweden, Australia; the analysis of the specifics of such training in different countries; determination of priority forms and methods of training specialists in social work. As a result of the analysis, it has been found out that the positive experience of social workers training in other countries can be used in Ukraine, taking into account the peculiarities and traditions of the national higher school.

Keywords: social work, social worker, professional training.

\section{Introduction}

The increase of a role and a status of social work in Ukraine caused by domestic economic and political realities, increasing the number of clients of social workers and the categories of them in the country actualize the problem of improving the professional training of specialists in social work in Ukrainian universities. The solution of this problem will be effective if professional training of future social workers will not only be based on the specifics of domestic social work and the best examples of domestic professional education, but also on the experience of training social workers abroad, where social work had the status of professional activity much earlier than in Ukraine.

The peculiarities of professional training of social workers in the USA, Canada, Great Britain, France, Sweden, Australia are revealed in the researches of such domestic scientists as N. Vydyshko [1], L. Vinnikova [2], O. Zahaiko [3], A. Kulikova [4], H. Leshchuk [5], O. Olkhovych [6], O. Pichkar [7], H. Slozanska [8], N. Sobchak [9], and others.

The aim of the article is to generalize the experience of professional training of social workers abroad and to analyze the possibilities of its implementation in domestic universities.

\section{Discussion}

Training social workers in different countries has its own characteristics. Thus, the analysis of the Canadian system of theoretical and practical training of social workers demonstrates its flexibility and effectiveness, which is provided by the availability of several types of training programs, selective and elective theoretical courses; clear sequence of learning disciplines; taking into account modern realities of social work in the subjects; compliance of humanitarian and professional courses; using different forms of educational work; credit system and so on. Students have the opportunity to choose theoretical courses among disciplines of humanitarian and professional cycles, and lecturers are personally responsible for the implementation of the program. Integration of theory and practice in the field of social work is implemented in Canada by interaction of professional schools with social agencies; forms of the organization of educational process which involves the existence of in-class learning and practical training in the agency during a learning week; studying elective theoretical courses on problem branches of social work; practical training in social agencies; training of instructors of practice (fulltime employees of social institutions) at the premises of colleges, faculties, schools or social work departments which are parts of universities [1].

The main priority of social worker training in the United States is an expanded field practice in social agencies, which provide social assistance, or in private charity organizations. Common blocks of disciplines for students of all levels of training in the United States is the theory of social work, human behavior, the influence of the social environment, practical activities in social institutions. Theoretical training is combined with practice in social agencies [2].

In Great Britain, the considerable attention is paid to the formation of the student population for the social sphere, careful selection of candidates for a profession of a social service worker is conducted. An obligatory element of the candidate selection is an interview conducted by lecturers of an educational institution, employers, social workers and users of social services (all of them are specially trained for professional selection). Assigning a personal tutor, who performs educational, evaluative, organizational, mediating, and social and pedagogical functions, to each student for the entire period of education is common for higher educational institutions in Great Britain, which train social workers for secondary schools [3].

Training social workers in Great Britain is aimed at providing them with the knowledge of national social work standards which provide partnership, mutual trust between social service workers and their clients, knowledge of theory and the models of social work with 
different social groups and age categories, the legislative base for providing social services in the region; development of professionalism of a social worker, which provides formation of the specific professional and personal qualities necessary for successful professional task performance; continuous professional and personal development of a social worker; observance of ethical standards of social work by social workers. Such training provides wide use of various special courses aimed at training social workers for work with children and teenagers; offenders and prisoners; with unhealthy (in the health care system) disabled people; old people; society; in the system of social protection, etc. [7].

For example, in Sweden, the potential of informal education, which is supported by social movement and public organizations, is widely used as well as formal higher education. Social workers usually lead such organizations and participate in various projects which they implement. Due to various projects (sports, social, educational, etc.) social workers and students are engaged in process of continuous cognitive activity. So informal education promotes the formation of leadership skills, active civil position, development of communicative skills, professional creativity of future social workers. "Lifelong learning" principle is provided with informal methods of training, first of all supervision and mentoring, which dominate in professional development of social workers and in the process of experience exchange, in particular with foreign colleagues [4].

The absence of a uniform nationwide standard in Australia and the autonomy of higher educational institutions in planning, organization and implementation of educational process has led to the fact that in different schools of social work in Australia there are significant differences in professional training of social workers, concerning the duration of training, logic and structure of the organization of educational process, the list and content of training courses, grading systems, requirements and conditions of passing examinations, samples of diplomas and so on.

The general approaches to creation of the professional training system of social workers in Australia are as follows: diagnostics of professional suitability of applicants for training (experience of work in a social institution, general level of development, tendencies, abilities, compliance with psychological requirements, etc.); the opportunity for the masters to choose the kind of professional training: the professional one, which allows to obtain a master's degree in practice; the research one providing the degree of a master-scientist in social work with the corresponding specialization ("Social work with individuals, groups and families", "Social management", "Children and family therapy", "Social work in a community", "Management of cross-cultural conflicts", "Clinical social work", "Medical social work", "Social work in the field of management", "Social protection", "Clinical social therapy", "Social researches", "Social policy", "Mediation", "Social work in rural areas", "Social securi- ty", "Public development"); professional training of doctors of social work is carried out at one of such types of educational and qualification levels: the professional one providing graduates with the doctor's degree in social work with specialization in the field of scientific research, and the research one, which provides a Ph.D. diploma indicating specialization in social work. The programs of postgraduate education provide professional development and retraining of social workers which is a necessary condition for receiving / updating of the license for practical activities. It is necessary to note that training of social workers in Australia is characterized by a practical orientation, introduction of innovative technologies, double degrees (bachelor's), a wide range of specializations in a master's programs, and the existence of supervisory institutions [8].

In France, enrollment of applicants for training in most specialties is also followed by a professional selection and provides passing entrance examinations to determine the general level of training of entrants, to clarify the psychological matching to the chosen specialty, psychological motivation for choosing social work as a profession. For most specialties, the practical experience of the entrant's activity in social field is a necessary condition. The French system of professional training of specialists in social field is characterized by the transversal nature of the content of education, the flexibility of professional training programs, the combination of invariant and variable components, the modular organization of the educational process, the integration of theoretical and practical components, the priority of the individual approach to the student, the modeling of future professional activity in the training process, cooperation of educational institutions with social institutions [5].

Concerning the forms and methods of training, the analysis of foreign experience of social workers' training demonstrates that in the United States and Canada training in small groups and individual training is preferable. Such forms of the organization of training as seminars, practical training, individual work, practical work, tutorials, design training, work in teams, individual additional consultation, individual consultation on personal problems, consultation in groups, consultation in special services (health care centers, preventive work centers, medical care and health insurance centers, assistance program centers, etc.), maintaining a student's workbook dominate. An innovative form of the organization of training is the so-called integrative seminar, which provides the development of reflexive abilities, the integration of students' theoretical knowledge and practical skills, their correction. Recently, virtual forms of training have become very popular: audio and visual presentations, video lectures, conferences, seminars, work in electronic libraries and on the Internet ([2], [6], [9]). For example, in Canada, in addition, innovative methods of teaching, such as "a facilitator in a group", written analysis of the activity of social services, the description and the analysis of "cases", the analysis of interviews, etc. are widely used [6]. 
In the process of social workers training, workshops, tutorials, project training, small group and team work, disputes, individual consultations, study and analysis of individual situations, presentations, as well as experimental tasks, modeling, essays, design of posters, portfolio and seminars online are used in Great Britain [3]. Individual forms of social workers' training also dominate over group work [7].

In Sweden, professional theoretical training of social workers of various levels is also carried out by means of a wide variety of methods and forms of training, the leading of which are lectures, conversations, discussions, consultations, business and role-playing games, trainings, methods of problem training, and so on. However, the training of social workers at the bachelor's and master's levels is dominated by group and micro-group forms of training, whereas at the research level is the individual one [4].

In our opinion, the experience of social education in Australia is no less interesting, where lectures-debates, lectures-consultations, lectures-abstracts, seminars-press conferences, practical training, individual consultations, induction and integrative seminars are used to train social workers. Dialogues, discussions, debates, interviews, monitoring, diagnostics, problem presentation of material, specially developed programs for electronic presentation of material, film demonstrations, individual and group exercises allow to activate the cognitive activity of Australian students. "Brainstorming", synectics, "morphological analysis", training in cooperation, as well as roleplaying games, work with a real case, a method of professional activity design, collecting and analysis of information, Internet conference, photo reports, TV programs, essay, etc. are widely used [8].

All these methods, means and forms of training are also used in the process of training future specialists in social field in France, but work in practice analysis groups, social expertise, drawing up a profile are more specific for it [5].

So, professional training of future social workers in different countries has many common features, which indicates the expediency and effectiveness of application

\section{REFERENCES}

1. Vydyshko, N. (2010). Profesiina pidhotovka maibutnikh sotsialnykh pratsivnykiv u koledzhakh Kanady [Professional training of future social workers at Canadian colleges]. Extended abstract of candidate's thesis. Vinnytsia [in Ukrainian].

2. Vinnikova, L. (2003). Systema pidhotovky sotsialnykh pratsivnykiv u vyshchykh navchalnykh zakladakh SShA [System of social workers' training in higher educational institutions of the USA]. Extended abstract of candidate's thesis. Luhansk [in Ukrainian].

3. Zahaiko, O. (2008). Pidhotovka pratsivnykiv sotsialnykh sluzhb dlia serednikh zahalnoosvitnikh navchalnykh zakladiv Velykoi Brytanii [Training social workers for general secondary schools of Great Britain]. Extended abstract of candidate's thesis. Kharkiv [in Ukrainian]. of these methods, means and forms for training specialists in social field.

\section{Conclusions}

The analysis of foreign experience of training specialists for social field makes it possible to provide suggestions for its use for improvement of the system of professional social education in Ukraine, namely: to develop and approve national standards of social work for all levels of professional education; to update curricula and programs according to requirements of the international standards; to provide professional selection of applicants for mastering the profession of a social worker; to develop the concept of specializations for different levels of training of specialists in social work, to develop optional special courses, to involve experienced social workers-practitioners for teaching; to provide the maximum practical orientation of professional training of social workers by increasing the duration of practice in social institutions, correcting the practice programs, expanding its types and bases, organizing practical experience management by experienced specialists in social work, attracting students to volunteer movement; to establish partnership cooperation between educational institutions and social organizations on the basis of mutual responsibility for the results of the process of professional training of future social workers, their social protection and employment; to intensify the participation of Ukrainian and foreign teachers and students in joint researches and projects in social field; to activate the exchange of teachers and students between the leading educational institutions of Ukraine and foreign countries; to provide a continuity of the process of social workers' professional training through the introduction of effective postgraduate education programs.

The positive experience of social workers' training in other countries can be used in Ukraine, taking into account the peculiarities and traditions of the national higher education. It will optimize the system of training social workers at various levels and will help to improve the social situation in Ukraine.

4. Kulikova, A. (2009). Pidhotovka sotsialnykh pratsivnykiv do roboty $\mathrm{z}$ ditmy ta moloddiu u vyshchykh navchalnykh zakladakh Shvetsii [Preparation of social workers for work with children and youth in higher educational institutions of Sweden]. Extended abstract of candidate's thesis. Luhansk [in Ukrainian].

5. Leshchuk, H. (2009). Systema profesiinoi pidhotovky fakhivtsiv sotsialnoi sfery u Frantsii [System of professional training of specialists in social field in France]. Extended abstract of candidate's thesis. Ternopil [in Ukrainian].

6. Olkhovych, O. (2008). Pidhotovka sotsialnykh pratsivnykiv do roboty $\mathrm{z}$ bizhentsiamy $\mathrm{u}$ vyshchykh navchalnykh zakladakh SShA i Kanady [Training social workers for work with refugees in higher educational 
institutions of the USA and Canada]. Extended abstract of candidate's thesis. Ternopil [in Ukrainian].

7. Pichkar, O. (2002). Systema pidhotovky fakhivtsiv sotsialnoi roboty u Velykii Brytanii [System of training specialists of social work in Great Britain]. Extended abstract of candidate's thesis. Ternopil [in Ukrainian].

8. Slozanska, H. (2011). Profesiina pidhotovka sotsialnykh pratsivnykiv u vyshchykh navchalnykh zakladakh Avstralii [Professional training of social workers

\section{ЛІТЕРАТУРА}

1. Видишко Н. В. Професійна підготовка майбутніх соціальних працівників у коледжах Канади : автореф. дис. на здобуття наук. ступ. канд. пед. наук : спец. 13.00.04 «Теорія і методика професійної освіти» / Н. В. Видишко. - Вінниця, 2010. - 21 с.

2. Віннікова Л. В. Система підготовки соціальних працівників у вищих навчальних закладах США : автореф. дис. на здобуття наук. ступ. канд. пед. наук : спец. 13.00.04 «Теорія і методика професійної освіти» / Л. В. Віннікова. - Луганськ, 2003. - 21 с.

3. Загайко О. В. Підготовка працівників соціальних служб для середніх загальноосвітніх навчальних закладів Великої Британії : автореф. дис. на здобуття наук. ступ. канд. пед. наук : спец. 13.00.01 «Загальна педагогіка та історія педагогіки» / О. В. Загайко. Харків, 2008. - 20 с.

4. Кулікова А. С. Підготовка соціальних працівників до роботи $з$ дітьми та молоддю у вищих навчальних закладах Швеції : автореф. дис. на здобуття наук. ступ. канд. пед. наук : спец. 13.00.05 «Соціальна педагогіка» / А. Є. Кулікова. - Луганськ, 2009. - 21 c.

5. Лещук Г. В. Система професійної підготовки фахівців соціальної сфери у Франції : автореф. дис. на здобуття наук. ступ. канд. пед. наук : спец. 13.00.04 in higher educational institutions of Australia]. Extended abstract of candidate's thesis. Ternopil [in Ukrainian].

9. Sobchak, N. (2004). Zmist i formy profesiinoi pidhotovky sotsialnykh pratsivnykiv u systemi neperervnoi osvity SShA [Contents and forms of professional training of social workers in the system of continuous education of the USA]. Extended abstract of candidate's thesis. Ternopil [in Ukrainian].

«Теорія і методика професійної освіти» / Г. В. Лещу. Тернопіль, 2009. - 20 с.

6. Ольхович О. В. Підготовка соціальних працівників до роботи з біженцями у вищих навчальних закладах США і Канади : автореф. дис. на здобуття наук. ступ. канд. пед. наук : спец. 13.00.04 «Теорія i методика професійної освіти» / О.В.Ольхович. Тернопіль, 2008. - 21 с.

7. Пічкар О. П. Система підготовки фахівців соціальної роботи у Великій Британії : автореф. дис. на здобуття наук. ступ. канд. пед. наук : спец. 13.00.05 «Теорія і методика професійної освіти» / О. П. Пічкар. - Тернопіль, 2002. - 21 с.

8. Слозанська Г. І. Професійна підготовка соціальних працівників у вищих навчальних закладах Австралії : автореф. дис. на здобуття наук. ступ. канд. пед. наук : спец. 13.00.04 «Теорія і методика професійної освіти» / Г. І. Слозанська. - Тернопіль, 2011. $-21 \mathrm{c}$.

9. Собчак Н. М. Зміст і форми професійної підготовки соціальних працівників у системі неперервної освіти сша : автореф. дис. на здобуття наук. ступ. канд. пед. наук : спец. 13.00.04 «теорія і методика професійної освіти» / Н. М. Собчак. - Тернопіль, 2004. $-21 \mathrm{c}$.

\section{Вікторія Вікторівна Корнещук, доктор педагогічних наук, професор, завідувач кафедри сочіальної роботи та кадрового менеджменту, Одеський національний політехнічний університет, проспект Шевченка, 1, м. Одеса, Украӥна}

\section{ПРОФЕСІЙНА ПІДГОТОВКА МАЙБУТНІХ СОЩІАЛЬНИХ ПРАЦІВНИКІВ: АНАЛІЗ ЗАРУБІЖНОГО ДОСВІДУ}

Статтю присвячено узагальненню досвіду професійної підготовки соціальних працівників у США, Канаді, Великій Британії, Франції, Швеції, Австралії; аналізу особливостей такої підготовки в різних країнах; визначенню пріоритетних форм і методів навчання фахівців із соціальної роботи. В результаті проведеного аналізу було з'ясовано, що позитивний досвід підготовки соціальних працівників в інших країнах може бути використаний в Україні з урахуванням особливостей і традицій вітчизняної вищої школи. Для оптимізації системи підготовки фахівців із соціальної роботи в Україні необхідно: розробити і затвердити загальнодержавні стандарти з соціальної роботи для всіх ланок професійної освіти; постійно оновлювати навчальні плани і програми відповідно до вимог світових стандартів; запровадити профвідбір абітурієнтів для оволодіння професією соціального працівника; розробити концепцію спеціалізацій для різних рівнів підготовки фахівців із соціальної роботи, підготувати відповідно до них вибіркові спеціальні курси, залучати для їх викладання досвідчених соціальних працівників-практиків; забезпечити максимальну практичну спрямованість професійної підготовки фахівців із соціальної роботи шляхом збільшення тривалості проходження практики студентами в соціальних установах, корекції програм практики, розширення її видів та баз проведення, організації керівництва практикою студентів 
досвідченими фахівцями в сфері соціальної роботи, залучення студентів до волонтерського руху; налагодити партнерську співпрацю між навчальними установами і соціальними організаціями на засадах взаємної відповідальності за результати процесу професійної підготовки майбутніх фахівців із соціальної роботи, їх соціальний захист і працевлаштування; активізувати участь українських та зарубіжних викладачів і студентів у спільних дослідженнях та проектах в соціальній сфері; активізувати обмін викладачами та студентами між провідними навчальними закладами України та за кордоном; забезпечити безперервність процесу професійної підготовки соціальних працівників за рахунок упровадження ефективних програм післядипломної освіти. Удосконалення професійної підготовки фахівців із соціальної роботи сприятиме покращенню соціальної ситуації в Україні.

Ключові слова: соціальна робота, соціальний працівник, професійна підготовка.

Submitted on March, 14, 2017

УДК: 378:17.202.1

Левон Рубенович Нікогосян, доктор медичних наук, доцент, завідувач кафедри загальної фармації, Юлія Олександрівна Асєєва, кандидат психологічних наук, старший викладач кафедри психіатрії, наркологї, психологї та сочіальної допомоги, Одеський національний медичний університет, пров. Валіховський, м. Одеса, Україна,

\section{АКСІОЛОГІЧНИЙ ПІДХІД У СИСТЕМІ ПРОФЕСІЙНО-ПЕДАГОГІЧНОӤ ПІДГОТОВКИ МАЙБУТНІХ ФАХІВЦІВ МЕДИЧНОЇ ГАЛУЗІ}

У статті визначено важливість системно-ціннісного підходу, подано характеристику аксіологічного підходу як методологічного концепту професійно-педагогічної підготовки майбутніх фахівців медичної галузі. Зазначено основні принщипи, функиії, моделі аксіологічного підходу та визначено пріоритетні цінності в освіті, вихованні та саморозвитку майбутніх фахівиів медичної галузі. Підкреслено, щуо аксіологічний підхід у системі професійно-педагогічної підготовки повинен бути орієнтований на формування системи иінностей, які відповідають вимогам, установленим до майбутніх фахівців медичної галузі.

Ключові слова: аксіологія, аксіологічний підхід, вищі навчальні заклади, студенти-медики, майбутні фахівияі медичної галузі.

\section{Постановка проблеми}

Формування ціннісної системи особистості вимагає постійного аналізу, оцінки подій, що відбуваються, в процесі життєдіяльності. Особистість постійно ставить перед собою певні завдання, приймає рішення, корегує та реалізує свої цілі. При цьому ставлення до навколишнього світу і визначення свого місця в ньому пов'язано 3 двома підходами - практичним і абстрактно-теоретичним (пізнавальним). Роль сполучної ланки між практичним і пізнавальним підходами виконує аксіологічний (ціннісний) підхід.

Аксіологія за філософськими словниками (грец. Axia - цінність, logos - слово, вчення) визначається як філософське дослідження природи цінностей $[1,2]$; як філософська дисципліна, що займається дослідженням цінностей як змістовно створюючих основ людського буття, які задають спрямованість і мотивацію людського життя, діяльності та конкретних дій і вчинків [3, 4]. У сучасних умовах аксіологія розглядається як теорія цінностей і характеризується істотним переміщенням уваги на загальнолюдські цінності, які визначаються в свідомості людей сучасними реаліями буття. Отже, центральним поняттям в аксіології $\epsilon$ поняття цінності, яке характеризує соціокультурне значення явищ дійсності, включених у ціннісні відносини.

Аксіологічний підхід властивий гуманістичному напрямкові, оскільки людина розглядається в ньому як найвища цінність суспільства і самоціль суспільного розвитку. Саме в цьому підході й знаходить своє відображення різноманітність ставлення до людини, суспільства, духовних цінностей, діяльності, що і визначає зміст гуманістичної сутності особистості. Останнім часом аксіологічний підхід активно використовується у дослідженні педагогічних проблем вищої школи, однак і досі не набув достатнього розкриття в професійній підготовці майбутніх фахівців медичної галузі.

Метою статті $\epsilon$ вивчення та аналіз літератури 3 проблеми дослідження, визначення місця та ролі аксіологічного підходу в процесі професійної підготовки майбутніх фахівців медичної галузі.

Методами дослідження було обрано порівняння, узагальнення та аналіз літератури з проблеми. 